\title{
Pre-employment exam analysis of a military company and its relation to oral health
}

Thaís Richter de Araújo', Dagmar de Paula Queluz ${ }^{1}$

${ }^{1}$ Department of Community Dentistry, Piracicaba Dental School, UNICAMP - University of Campinas, Piracicaba, SP, Brazil

\begin{abstract}
Absenteeism is determined as an absence from work, resulting in the decrease of the company's production and, consequentially, causing profit reduction. The employer must follow closely the employees' quality of life, assuring that they perform all their tasks effectively. Dental health is directly connected to the employee's general health status and cannot be put aside when trying to assure complete physical and mental well being of an individual. Aim: To analyze preemployment exams of a military company in order to identify, among all the reasons for exclusion, dental problems that ultimately resulted prevented hiring of job applicants. Methods: Information was collected in 2008 from the dental files of the Health Department archives, which contained data referring to the candidates applying for a specific position and permitted and analytical study of the reasons for exclusion, based on the International Classification of Diseases (ICD-10). Results: $10.24 \%$ (720) of the candidates, from a total of 7,029, were excluded for dental reasons, namely dental cavitation, $2.8 \%$ (197), and pulpal and periapical diseases, $3.14 \%$ (221). Conclusions: Aside from being limited, the results of this study suggest that dental problems influence a great deal on the quality of life of employees that are able for work, and, that being said, should be managed closely to reduce absenteeism in the workplace.
\end{abstract}

Keywords: occupational health program, oral health, occupational dentistry.

\section{Introduction}

Facing a highly globalized world, where the economy exerts incisive influence on corporate productivity and the quality of services and products, there has been the need to reduce operating costs in order to increase competitiveness and profits $^{1}$. With that, important aspects, such as physical and mental well-being of the worker have been overlooked.

The quality of life of workers is an issue that deserves attention, since the promotion of welfare benefits, such as medical and dental care to employees, are extremely efficient means and can be used by businesses in order to improve inter business competitiveness, in a globalized world ${ }^{2-4}$.

The health of workers is seen in the context of their quality of life. Recently,

Received for publication: August 22, 2013 Accepted: November 18, 2013

Correspondence to: Dagmar de Paula Queluz Departamento de Odontologia Social Faculdade de Odontologia de Piracicaba - UNICAMP Avenida Limeira, 901, CEP: 13414900

Piracicaba, SP, Brasil Phone: +55 1921065277

E-mail: dagmar@fop.unicamp.br companies have implemented Health Promotion actions in order to benefit their workers. With this, dental care begins to be viewed favorably, as workers with the welfare provided by the company are more healthy and satisfied, and therefore, produce with better quality and in greater quantity ${ }^{5}$.

The first step to ensure the workers' quality of life in their working environment, is conducting pre-employment exams. The Ministry of Labor advocates and demands, through Ordinance 3214, regulated by NR 7 (regulatory standards) that all employees undergo a medical evaluation before the start of hiring and activities ${ }^{6-9}$. 
A brief comment is opportune on the regulation rules approved by the law 3214/78 of the Government Labor Department and the subsequent norms issued by General Safety Office and Medicine of the Work ${ }^{6}$. They are obligatory for the private and public enterprises and for the direct and indirect administration public organs, as well as for Legislative and Judiciary organs that hire by the Consolidation of the Laws of Work rules. The dispositions also apply, where it fits, to the entities or companies that hire workers and the representative unions of the respective professional categories. The General Safety Office and Workers Health Department is the organ of Government Labor Department in charge of coordinating, guiding, controlling, supervising the activities related with the Work Safety and Medicine, and to supervise the fulfillment of legal precepts and regulations ${ }^{7,8}$. There are 36 regulation rules (NR) and the NR 7 is one of them ${ }^{9}$. For many years, a direct relationship was observed between the worker's activity and type of acquired diseases, and recently generated a rising interest to protection at the workplace.

Making a historical overview, Domingues ${ }^{10}$ writing about the periodic medical examination, reminded that it was England that initially established inspection of workshops in 1842, forbade the labor of women and children in underground and for the first time, James Smith hired a "factory doctor" in 1879. The first English Work Accident law was approved in 1890 , the workday was limited to 8 daily hours, and therefore, 48-h working week. The author mentions that the developed societies understood that preservation of the worker's health and physical integrity provides both their personal, family and social welfare, as evidenced by increased productivity and reduces spending on insurance and social security claims.

The occupational dentistry emerged as a specialty in Brazil, set by the Federal Council of Dentistry through Resolution $22 / 2001^{11,12}$. The inclusion of occupational dentistry is evidenced in the armed forces, military police and firefighters, even without the lawful requirements, by admitting candidates to vacancies as well as for service to all its members, avoiding disorders that may result in work environment, such as pain, absenteeism and accidents.

Guimarães and Rock ${ }^{13}$ define occupational dentistry as "the part of dentistry that relates to promoting, preserving and repairing the worker's health, resulting from injuries, illnesses or diseases from their professional practice and that manifest in the mouth" differs from the other specialties to have their action directly and directed toward the prevention of occupational problems, keeping in mind the prevention of diseases resulting from occupational activity and accidents.

Gomes and Magalhães ${ }^{14}$ suggested the workplace oral census as an important preventive measure. This census consists in a collective examination of workers to identify oral manifestations of professional diseases and foci of dental etiology, determine the prevalence of caries and periodontal disease, and plan the treatment in a rational manner. The company's dental service should be seen as primarily directed to the oral health of the employees and their welfare, while representing the company's economic interests by keeping the worker fit to produce more and better, with low or no absenteeism, which means having the return of the investment on the health care. With the benefit of dental care, the worker will have fewer absences, decreasing or eliminating the problem of the absence certificate.

The pre-employment exam is performed before the employees assume their activities and aims: to know the state of health of the applicant; observe the compatibility conditions between the prospective employee and the tasks to be performed; protect future employees from activities for which they are not physically qualified; detect diseases at an early stage and to protect employees from contagious diseases; diagnose oral and systemic diseases manifest in the oral cavity and detect morbidities that contraindicate the candidate's desired function. However, it should not be used to discriminate against applicants because of injuries that do not interfere with the performance and safety to perform his/her tasks?.

Based on this understanding, occupational dental exams effectively integrate the Medical Control Program in Occupational Health (PCMSO) and must be undertaken in a complementary way $^{6-9}$. According to NR 7, the mandatory occupational tests are limited only to medical evaluations, since the NR 4 does not yet recognize dentist's work as part of the Occupational Health and Medical Control Program (PCMSO). Currently, dental occupational tests are wrongly only optional exams. In addition to this pre-employment exam, other occupational queries, such as periodic exams, dismissal, change of function and return to work, shall be subject to a pre-established program (PCMSO) and risks identified by the Program for Prevention of Environmental Risks (PPRA). This means that such tests cannot be loose queries, must be linked to PCMSO and targeted to specific risks, according to a predetermined pattern.

Each company may have a range of requirements and advise the applicant to solve dental problems before admission, or demand that he provides to do so after admission.

Among other data, the Occupational Health Certificate (ASO) must contain the function, identified risks, procedures (according to PCMSO) and completion of fitness, and state that, in the understanding of the professional who signs it, the job candidate shows no pathology that could be worsened by the work, has no disease or physical condition that may put others at greater risk and is physically qualified for the task.This is one way that the company must ensure that a worker being hired, has adequate health to perform the functions appropriate to the position. Consequently, these pre-employment exams will contribute to absenteeism dwindling in the company.

The International Labor Organization defines absenteeism as not reporting to work by the employee, excluding periods of holidays or strike. Midorikawa ${ }^{15}$ defined absenteeism in two different types. Type I, or lack of work, is the sheer absence from work, which leads to loss of production and hours not worked. Type II, is one in which the worker has a health problem, although he does not miss work, but it does not allow him/her to perform its functions 
in the best possible way, which will bring a decrease in productivity.

Given all questions of the physical well being linked to absenteeism, there are dental problems. However, studies on the subject are scarce and often present controversial results regarding the influence of dental problems in absence from work $^{16-20}$. Anyway, studies suggest that easy access to dental treatment to workers could decrease the impact caused by these dental problems ${ }^{15}$.

The worker's quality of life is an issue that deserves our attention, since the promotion of benefits such as medical and dental care to employees, are extremely efficient means and can be used by businesses to improve competitiveness inter-business, in this globalized world.

The worker's health is seen in the context of his/her quality of life. In the last few years, Health Promotion actions were implemented in companies in order to benefit their workers. With this, dental care starts to be favorably viewed, as workers with the benefit provided by the company are more healthy and satisfied, and therefore, produce with better quality and greater quantity.

The objective of the present study was to analyze preemployment exam of a military company, identifying dental problems in all the reasons for exclusion, which ultimately prevent the hiring of the employee by the company.

\section{Material and methods}

The research protocol was reviewed and approved by the Ethics Committee of the University of Campinas (UNICAMP) under registration number 050/2009.

This was a retrospective epidemiological study, based on the Health Department Inspection of the military company of a city in the state of São Paulo.

The information was collected in 2008, from the medical and dental files of the archives of the Health Department, which contained pre-employment exams data on the individual candidates applying for the concerned job; allowing the analytical study of exclusion based on International Classification of Diseases (ICD-10) code of disease

The pre-employment exams were performed by previously selected and trained diagnostic examiners and calibration necessary for avoiding difference, and conduct reports in order to contribute to an analysis of the results of health inspections of individuals and suggest measures for future inspections; report on the possibilities of collaboration in the selection by the civilian and military health professionals in the locality.

For the variables worksheet health inspection, the following classifications and criteria were used: preemployment exams (ICD-10, date of exam, evaluation: fit or unfit), distribution by the ICD-10 codes of disease (DENTAL PROBLEMS: K00 Anodontia; K02 Tooth Decay; K04 Pulpitis; K05 Gingivitis and periodontal problems; K07 Dento-facial anomalies (including malocclusion); K08 Other disorders of the teeth and their supporting structures; K10 Other diseases of jaws; K12 Stomatitis and related lesions.
MEDICAL PROBLEMS: K40 Inguinal hernia; K60 Fissure and fistula of anal and rectal regions; K76 Other diseases of liver; E03 Other hipotireoidismos; E46 Protein-calorie malnutrition unspecified; E66 Obesity; F41/42 Panic disorder [episodic paroxysmal anxiety]/Obsessive-compulsive disorder; G40 Epilepsy; H52 Hypermetropia; J45 Asthma; L70 Acne; L81 Other disorders of pigmentation; M21 Other acquired deformities of limbs; M22 Disorders of patella; M23 Knee Problems; M40 Kyphosis and Lordosis; M41 Scoliosis; N50 Other disorders of male genital tract; R01 Murmurs and other heart sounds; S52 Fracture of forearm; others\}.

Data were statistically analyzed using descriptive analysis (frequency, percentage). The analyses were performed using SAS software version 9.1. The data were grouped in two groups, differentiated by the dates of the performed tests. Group I inspected between days July 8 until September 5 and the Group II inspected from September 15 until October 10, year 2008; with all male individuals, aged from 18 to 25 years and candidates exercising the same function locally.

\section{Results}

A total of 7,029 subjects were examined with the potential to work based on the medical and dental statements of the archives of the Health Department.

The results from an analysis of pre-employment exams were: $10.24 \%(\mathrm{n}=720)$ of the candidates, from a total of 7,029 were excluded for dental reasons, such as tooth decay, $2.8 \%(\mathrm{n}=197)$, and pulp and periapical problems, $3.14 \%$ $(\mathrm{n}=221)$. Besides limiting, a dental problem plays an eminent role in the quality of life of employees able to work and thus increases the possibility of reducing absenteeism in the workplace.

The highest prevalence of dental problems in Group 1 were K02 Tooth Decay $(\mathrm{n}=123)$ and K04 Pulpitis and periapical problems $(n=92,27.5 \%)$, while in Group 2 were K04 Pulpitis and periapical problems $(n=129,33.5 \%)$ and K07 Dento-facial anomalies including malocclusion $(\mathrm{n}=94$, 24.4\%) (Table 1).

Among the medical problems that prevented hiring of the individual, a large number of unfit for ocular reasons were observed (hypermetropia 10.6\%, 748 individuals excluded for this reason, from a total of 7,029$)$, postural problems, deformities in knee or patella $(10.97 \%, 771$ excluded individuals from the same total), acquired deformities in the limbs (5.4\% - 377 individuals excluded) and obesity $(3.95 \%, 278$ individuals). Exclusion was due to the fact that these diseases are highly limiting motor/physical performance of individuals, which would result in a decrease in the potential implementation of the activities on the proposed functions (Table 1).

\section{Discussion}

There are necessities of qualifications to the Armed Forces (military company); therefore, it requires high standards from the candidate for a positions ${ }^{21-28}$. 
Table 1: Distribution of absolute and relative frequency of variables by servicemen group in 2008.

\begin{tabular}{|c|c|c|c|}
\hline Variables & & $\begin{array}{c}\text { Group } 1 \\
\mathrm{n}(\%)\end{array}$ & $\begin{array}{c}\text { Group } 2 \\
n(\%)\end{array}$ \\
\hline \multirow{3}{*}{ Evaluation } & Unfit (not hired) & $1,490(72.3)$ & $3,356(67.5)$ \\
\hline & Fit & $570(27.7)$ & $1,613(32.5)$ \\
\hline & Total & $2,060(100.0)$ & $4,969(100.0)$ \\
\hline \multirow{3}{*}{ Reason for not hiring } & Medical problems & $1,155(77.5)$ & $2,971(88.5)$ \\
\hline & Dental problems & $335(22.5)$ & $385(11.5)$ \\
\hline & Total & $1490(100.0)$ & $3,356(100.0)$ \\
\hline \multirow{9}{*}{$\begin{array}{l}\text { ICD dental problems that prevented } \\
\text { hiring }\end{array}$} & Ko0 Anodontia & $18(5.4)$ & $23(6.0)$ \\
\hline & K02 Tooth Decay & $123(36.7)$ & $74(19.2)$ \\
\hline & K04 Pulpitis and periapical problems & $92(27.5)$ & $129(33.5)$ \\
\hline & K05 Gingivitis and periodontal problems & $6(1.8)$ & $11(2.9)$ \\
\hline & K07 Dento-facial anomalies including malocclusion & $55(16.4)$ & $94(24.4)$ \\
\hline & $\begin{array}{l}\text { K08 Other disorders of teeth and their supporting } \\
\text { structures }\end{array}$ & $41(12.2)$ & $52(13.5)$ \\
\hline & K10 Other diseases of jaws & 0 & $1(0.25)$ \\
\hline & K12 Stomatitis and related lesions & 0 & $1(0.25)$ \\
\hline & Total & $335(100.0)$ & $385(100.0)$ \\
\hline \multirow{22}{*}{$\begin{array}{l}\text { ICD medical problems that prevented } \\
\text { hiring }\end{array}$} & K40 Inguinal hernia & 5 & 13 \\
\hline & K60 Fissure and fistula of anal and rectal regions & 1 & 1 \\
\hline & K76 Other diseases ofl iver & 0 & 1 \\
\hline & E03 Other hypothyroidism & 1 & 18 \\
\hline & E46 Protein-calorie malnutrition unspecified & 62 & 72 \\
\hline & E66 Obesity & 88 & 190 \\
\hline & $\begin{array}{c}\text { F41/42 Panic disorder [episodic paroxysmal anxiety]/ } \\
\text { Obsessive-compulsive disorder }\end{array}$ & 3 & 27 \\
\hline & G40 Epilepsy & 15 & 40 \\
\hline & H52 Hypermetropia & 153 & 595 \\
\hline & J45 Asthma & 35 & 149 \\
\hline & L70 Acne & 20 & 33 \\
\hline & L81 Other disorders of pigmentation & 53 & 102 \\
\hline & M21 Other acquired deformities ofl imbs & 145 & 232 \\
\hline & M22 Disorders of patella & 5 & 34 \\
\hline & M23 Knee Problems & 63 & 129 \\
\hline & M40 Kyphosis and Lordosis & 72 & 172 \\
\hline & M41 Scoliosis & 76 & 220 \\
\hline & N50 Other disorders of male genital tract & 15 & 62 \\
\hline & R01 Murmurs and other heart sounds & 60 & 138 \\
\hline & S52 Fracture of forearm & 16 & 35 \\
\hline & Other & 267 & 708 \\
\hline & Total & 1155 & 2971 \\
\hline
\end{tabular}


According to Araujo and Gonini $\mathrm{Jr}^{28}$, working conditions affect the quality of life of workers in oral health and may trigger changes in the oral mucosa, trauma and other injuries. They indicate the need for initial and periodic dental examinations as an information system on occupational health, thus ensuring a better quality of life for workers. Making regular dental examinations, oral diseases related to work could be detected.

The exclusion of subjects was due to the fact that a person with upcoming dental problems tends to have symptomatic problems in the future, and consequently would distract them from the main focus of the profession, and disrupting the community as a whole. The individual fit for work needs good oral health conditions without missing teeth or oral infections.

Military professionals live with risk throughout their career. Be it in training, in daily life or at war, there is always the possibility of imminent physical harm or death. When joining the Armed Forces, the military has the obligation to obey strict disciplinary rules and hierarchical principles, which condition all his/her personal and professional life. The military cannot engage in any other occupation, which makes him dependent on the Army.

The military tasks, not only in connection with possible conflicts, require high level of physical and mental health. The military is subjected throughout his career, periodic medical, dental examinations and physical fitness tests, to stay in active service. Therefore, the entrance examinations of individuals are very strict and certain diseases limit access to the Armed Forces. Fitness is required as to the general and dental health, in view of the compatibility of the individual with the routine and demands of the work to be performed on site.

Of the total of 7,029 individuals, a select group of 6,309 individuals had good oral health, showed no dental problems that could prevent the recruitment by the concerned company. One should point out, however, that many were just in medical or dental treatment for over a year. In total, $10.97 \%$ of subjects $(n=771)$ had postural problems, degenerative lesions of the knee and patella.

Regarding the dental conditions, the results showed the existing contrasts in the studied population. There were individuals with good oral health status (6,309 individuals), including those who are or were undergoing orthodontic treatment, and others with poor oral health, with partial or completely destroyed teeth or residual roots, indicating limited or no access to dental services. This fact highlights the lack of an intensive prevention program of oral problems and lack of dental care for the low-income population.

Although it was not the purpose of the study, we analyzed the state of nutrition of the subjects. Many individuals had protein-calorie malnutrition (134, which corresponded to 1.91 $\%$ of the total population), which was evidenced by short stature, low weight and soft tissue signs of malnutrition. Moreover, an expressive number of obese individuals (278, corresponding to $3.95 \%$ of the total population), characterized by high body weight, lack of frequent physical activity and inadequate and unbalanced diet.
Inadequate nutrition, characterized by excessive consumption of sweets and fats and insufficient intake of essential nutrients, factors responsible for the large number of obese and malnourished individuals was found, 412 individuals in total, corresponding to $5.8 \%$ of the total population.

Studies by Holst and Schüller ${ }^{29}$ indicate a strong influence of social context on the behavioral and psychological aspects, and the latter on the biological process in oral health, with considerable emphasis on dental caries. The opinion on oral health presented by the World Health Organization in 2003, showed the influence of socio cultural and environmental aspects of the oral health status factors, with the worst results among groups with poor living conditions and with traditions, beliefs and culture that do not favor oral health.

Sheiham et al. ${ }^{30}$ consider the individual quality of life greatly influenced by the oral health condition. Physical and psychological constraints can directly influence aspects of eating, speech, mobility, social interaction and self -esteem.

Lion \& Sheiham ${ }^{31}$ advocate that different levels of oral health have different influence in daily life and it is expected that in the study of the oral health needs of individuals, social and psychosocial dimensions be considered equivalent to the clinical conditions.

Reisine et al..$^{32}$, studying the suitability of using indicators of quality of life in dentistry, concluded that they are sensitive in the identification and description of the impact on different oral clinical conditions.

In conclusion, the analysis of pre-employment exams of a military company revealed that $10.24 \%$ of job applicants were excluded for dental reasons, with dental caries and pulpal and periapical problems having the highest prevalence. Aside from being limited, the results of this study suggest that dental problems influence a great deal on the quality of life of job applicants and employees that are able for work, and, that being said, should be managed closely to reduce absenteeism in the workplace.

\section{References}

1. Hollister MC, Weintraub JA. The association of oral status with systemic health, quality of life, and economic productivity. J Dent Educ. 1993; 57 : 901-12.

2. Macedo CG, Queluz DP. Quality of life and self-perceived oral health among workers from a furniture industry. Braz J Oral Sci. 2011; 10: 226-32.

3. Richardson JD, Long ME, Pedlar D, Elhai JD. Posttraumatic stress disorder and health-related quality of life among a sample of treatment-and pension-seeking deployed Canadian Forces peacekeeping veterans. Can J Psychiatry. 2008; 53: 594-600.

4. Voelker MD, Saag KG, Schwartz DA, Chrischilles E, Clarke WR, Woolson RF, et al. Health-related quality of life in Gulf War era military personnel. Am J Epidemiol. 2002; 155: 899-907. doi: 10.1093/aje/ 155.10.899.

5. Sheiham A, Steele JG, Marcenes W, Tsakos G, Finch S, Walls AWG. Prevalence of impacts of dental and oral disorders and their effects on eating among older people; a national survey in Great Britain. Community Dent Oral Epidemiol 2001; 29:195-203. 
6. Brazil. Ministry of Labor and Employment. 2013 [cited 2013 Aug 21]. Available from: http://www.mte.gov.br.

7. Brazil. Ministry of Health. Representation in Brazil OPA / WHO. Workrelated diseases. Procedures Manual for Health Services Brasilia: Ministry of Health; 2001.580p. Portuguese.

8. Brazil, Ministry of Health. Department of Health Care Department of Strategic Programmatic Actions. Health legislation: legislation in terms of worker health / Ministry of Health. 2 ed. Brasilia: Ministry of Health; 2004. 380p. Portuguese.

9. Brazil. Ministry of Labor and Employment. Regulatory Standards. Brasilia: Labor and Employment; 2013 [cited 2013 Aug 21]. Available from: http:/ /portal.mte.gov.br/legislacao/normas-regulamentadoras-1.htm.

10. Domingues JMM. Periodic medical examination. [cited 2013 Aug 21] . Available from: http://www.fundacentro.sc.gov.br/areas/8.pdf.

11. Brazilian Federal Dentistry Council CFO-22/2001 and CFO-25/2002. [cited 2013 Aug 21] . Available from: http://www.cfo.org.br.

12. Queluz DP. Labour Dentistry: a new specialty in Dentistry. Braz J Oral Sci. 2005; 4: 766-772.

13. Guimarães E, Rocha AA. [Dental work: organization of dental services from a company. $1^{\text {a }}$ part.] Odontol Mod. 1979; 6: 7-12.

14. Gomes EB, Magalhães $\mathrm{H}$. Oral census in company: its importance in the planning of dental care. Odontol Mod. 1980; 7: 31-8.

15. Midorikawa ET. Odontology in worker's health as a new professional specialty: definition of the activity field and functions of the surgeon dentist in worker's health team [doctor thesis]. São Paulo: Faculdade de Odontologia, Universidade de São Paulo; 2000. 337p. Portuguese.

16. Biron M, Bamberger P. Aversive workplace conditions and absenteeism: taking referent group norms and supervisor support into account. J Appl Psychol. 2012; 97: 901-12.

17. Griep RH, Rotenberg L, Chor D, Toivanen S, Landisbergis P. Beyond simple approaches to studying the association between work characteristics and absenteeism: combining DCS and ERI models. Work Stress. 2010; 24: 179-95.

18. Macedo CG, Queluz DP. Medical and dental absenteeism in workers from a furniture industry in Itatiba, SP, Brazil. Braz J Oral Sci. 2010; 9: 443-8.

19. Nardi A, Michel-Crosato E, Biazevic MGH, Crosato E, Pizzatto E, Queluz DP. Relationship between orofacial pain and absenteeism among workers in Southern Brazil. Braz J Oral Sci. 2009; 8: 50-4.

20. Markham SE, McKee GH. Declining organizational size and increasing unemployment rates: Predicting employee absenteeism from within- and between-plant perspectives, Acad Manage J. 1991; 34: 952-65.

21. Brazil. Brazilian Armed Forces: Brasília [cited 2013 Aug 21]. Available from: http://www.exercito.gov.br/.

22. Tausig M, Fenwick R. Work and mental health in a social context. New York, NY: Springer; 2011.

23. Woodhead C, Rona RJ, Iversen AC, MacManus D, Hotopf M, Dean K, et al. Health of national service veterans: an analysis of a communitybased sample using data from the 2007 Adult Psychiatric Morbidity Survey of England. Soc Psychiatry Psychiatr Epidemiol. 2011; 46: 559-566.

24. Richardson JD, Long ME, Pedlar D, Elhai JD. Posttraumatic stress disorder and health-related quality of life among a sample of treatment- and pension-seeking deployed Canadian Forces peacekeeping veterans. Can J Psychiatry. 2008; 53: 594-600.

25. Miloshevskii AV; Askerko NV; Ustimenko LI; Pleskach VV; Burtsev $\mathrm{NN}$; Tur luS. [Health, morbidity and injury rate among the north fleet seafaring personnel]. Aviakosm Ekolog Med; 2013; 47: 13-20.

26. Suman M, Spalj S, Plancak D, Dukic W, Juric $H$. The influence of war on the oral health of professional soldiers. Int Dent J. 2008; 58: 71-4.

27. Klimov AS, Grebnev GA, Slivkin AA, lordanishvili AK, Potrakhov NN. [About improvement of outpatient dental health service for young serviceman]. Voen Med Zh 2013; 334: 4-12.

28. Araujo ME, Gonini Júnior $A$. Worker oral health: the admission examinations and periodic as a system of health information. Odontol e Soc. 1999; $1: 15-8$.
29. Holst D, Schüller AA. Oral health changes in an adult Norwegian population: a cohort analytical approach. Community Dent Oral Epidemiol. 2000; 28: 102-11.

30. Sheiham A, Steele JG, Marcenes W, Tsakos G, Finch S, Walls AWG. Prevalence of impacts of dental and oral disorders and their effects on eating among older people; a national survey in Great Britain. Community Dent Oral Epidemiol. 2001; 29: 195-203.

31. LeãoA, Sheiham A. Relation between clinical dental status and subjectives impacts on daily living. J Dent Res. 1995; 74:1408-13.

32. Reisine ST. The impact of dental condition on social functioning and quality of life. Annu Rev Public Health. 1988; 9: 1-19. 